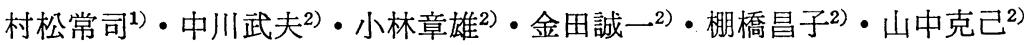

1）愛知教育大学養護教育教室

2）名古屋大学医学部公衆衛生学教室

要約 名古屋市内 $\mathrm{M}$ 保健所において通常行われている 3 才児健康診査の項目に重心動摇計 による検査を加え，3才児の重心動摇の測定を行った結果以下の様な成績を得た。

1）重心動摇計による 3 才児の検査では約半数の者が検査を完了するととができ，その割 合は男子より女子の方が高かった。

2）重心動摇面積ならびに重心動摇距離において開眼, 閉眼とも性差が認められ女子の方 が小さい值を示した。

3）重心動摇面積ならびに重心動摇距離の分布は男女とも近似的に対数正規分布を示して いる。

はじめに

1961年厚生省の告示が公布されて以来, 現在まで 3 才児健康診査は実施されてきたが，3才児期は身体発 育, 運動機能発達, 精神機能発達のいずれの面におい ても重要であるため，3才児健診に関する研究や調査 結果が多数報告されている。身体発育の面からの報告 （堀田, 1967 1968), 精神発達を中心とした報告（伊 藤他，1970；鈴木，1970)，運動機能面加らの報 告 （横田他，1972・1972）等が主であるが，3才児健診 の方法そのあのに関しても船川ら（1968・1968）によ って大規模に行われている。

そこで, 我々は 3 才児期の平衡機能感覚に拉ける男 女差に着目し，名古屋市内M保健所において通常行わ れている 3 才児健診に重心動摇計による検査を加え て，3才児について重心動摇の面から検討を試みた。

\section{調査期間ならびに調查対象}

調査は昭和 51 年 11 月から昭和 52 年 10 月までの 1 年 間，毎週 1 回実施された。

調査対象者は名古屋市内M保健所の 3 才児健診に来 所した1738名（男子 951 名，女子 787 名）の 3 才児で ある。

調査内容ならびに調査方法

1) 問診 (主としてアンケート調査)

2) 診察 (主として打聴診)

3）身体計測 (身長, 体重, 足長, 足幅)

4) 重心動摇計による検査
被検者 ( 3 才児) を検出台 (高さ $50 \mathrm{~mm}$ ) の上に 両足を揃えた状態 (開眼, 閉眼とも20秒間) で立た せ,その時の重心図 Electrogravitiogram (EGG) を記録した。なお重心動摇面積, 重心動摇距離は自動 解析によって算出した。

使用した機器は Gravicorder (アニマ製 Model G1800)である。

なお被検者には前もうて測定の状態を見させ，納得 させたうえで検出台に乗せた。検出台の前には母親を すわらせ，介助者が足を揃えて姿勢を矯正した。

\section{調 査 結 果}

重心動摇計による検査成績は表 1 に示すようであ る。グループ A は20秒間両足を揃えて動かずに測定が 完了できたものであり，開眼で男子 $43.7 \%$ ，女子 63.0 \%, 閉眼で男子 $38.4 \%$, 女子 $55.4 \%$ あった。開眼で 約20\%, 閉眼で約17\%女子の方が良かった。グループ B は20秒間は足を揃えていたが，顔や腕などを動かし た者であり, 開眼で男子 $23.6 \%$, 女子 $17.0 \%$, 閉眼で 男子 $12.3 \%$ ，女子 $8.9 \%$ あった。またグループCは 足を開いてしまった者, 泣いてしまった者, 検出台か ら降りてしまった者などであり，開眼で男子 $32.6 \%$, 女子 $20.0 \%$, 閉眼で男子 $49.4 \%$, 女子 $35.7 \%$ あっ た。

そこで, 今回 3 才児の重心動摇の資料としては開 眼，閉眼ともAグループの者（男子 283 名，女子 376 名）の値を用いることにした。

月令別にみた重心動摇面積（開，閉)，重心動摇距 
Table 1. Number of subjects.

\begin{tabular}{|c|c|c|c|c|c|c|c|}
\hline & \multicolumn{4}{|c|}{ eyes open } & \multicolumn{3}{|c|}{ eyes closed } \\
\hline & total & A & $\mathrm{B}$ & $\mathrm{C}$ & A & B & $\mathrm{C}$ \\
\hline Boys & 951 & $416(43.7)$ & $225(23.6)$ & $310(32.6)$ & $365(38.4)$ & $117(12.3)$ & $469(49.4)$ \\
\hline Glrls & 787 & $496(63.0)$ & $134(17.0)$ & $157(20.0)$ & $436(55.4)$ & $70(8.9)$ & $281(35.7)$ \\
\hline Total & 1738 & $912(52.4)$ & $359(20.7)$ & $467(26.9)$ & $801(46.1)$ & $187(10.8)$ & $750(43.2)$ \\
\hline
\end{tabular}

Group A: They were standing straight and still on the gravicorder.

Group B: They were standing straight on the gravicorder, but moved a little.

Group C: Others; they cried and ran away.

( ) : $\%$

Table 2. Means and standard deviations for area and length of electrogravitiogram (EGG) differentiated by the age group in month.

\begin{tabular}{|c|c|c|c|c|c|c|c|}
\hline & \multicolumn{4}{|c|}{ eyes open } & \multicolumn{3}{|c|}{ eyes closed } \\
\hline & \multicolumn{2}{|r|}{ Boys } & Girls & Total & Boys & Girls & Total \\
\hline & month & $\overline{\mathrm{X}} \quad$ S.D. & $\bar{X} \quad$ S.D. & $\bar{X}$ S.D. & $\bar{X}$ S.D. & S. D. & $\bar{X}$ S.D. \\
\hline \multirow{4}{*}{$\begin{array}{l}\text { Area of } \\
\text { EGG } \\
\left(\mathrm{cm}^{2} / 20 \mathrm{~s}\right)\end{array}$} & 36 & $16.3(7.6)$ & $15.0(7.2)$ & $15.6(7.4)$ & $27.2(14.8)$ & $22.4(11.9)$ & $24.3(13.3)$ \\
\hline & 37 & $16.1(7.3)$ & $15.5(7.8)$ & $15.7(7.6)$ & $25.0(11.6)$ & $20.5(11.0)$ & $22.5(11.5)$ \\
\hline & 38 & $16.9(3.3)$ & $15.1(6.0)$ & $15.8(5.2)$ & $27.8(10.3)$ & $22.4(12.1)$ & $24.4(11.6)$ \\
\hline & $39-$ & $14.4(3.3)$ & $10.9(3.6)$ & $12.1(4.7)$ & $28.9(15.3)$ & $15.2(7.4)$ & $20.0(12.3)$ \\
\hline \multirow{4}{*}{$\begin{array}{l}\text { Length of } \\
\qquad \mathrm{EGG} \\
(\mathrm{cm} / 20 \mathrm{~s})\end{array}$} & 36 & $54.5(13.8)$ & $51.1(14.7)$ & $52.5(14.4)$ & $90.0(32.0)$ & $72.9(25.5)$ & $79.8(29.5)$ \\
\hline & 37 & $52.1(16.3)$ & $51.6(14.2)$ & $51.8(15.2)$ & $80.5(28.2)$ & $69.6(24.3)$ & $74.5(26.6)$ \\
\hline & 38 & $51.7(11.4)$ & $53.2(13.8)$ & $52.6(12.8)$ & $85.3(29.0)$ & $73.1(33.9)$ & $77.6(32.3)$ \\
\hline & $39-$ & $45.2(11.3)$ & $39.8(11.3)$ & $41.7(11.1)$ & $70.5(10.2)$ & $61.5(19.0)$ & $64.7(16.6)$ \\
\hline
\end{tabular}

Number of Subjects: Boys ( 36 months $=88,37$ months $=179,38$ months $=11,39$ months $=2)$

: Girls (36 months $=129,37$ months $=219,38$ months $=19,39$ months $=4$ )

離 (開, 閉) は表 2 に示すようである。月令39ケ月以 上の者の平均値および標準偏差は男子閉眼重心動摇面 積を除いて, 顕著に小さかった。そのため更に月令39 ケ月以上の者を除いて最終的に男子 278 名, 女子 367 名（月令36〜38ケ月で閉眼，開眼ともAグループの 者)の值を用いることにした。

開眼，閉眼ともにAグループで月令36〜38ケ月の者 のそれぞれの值は表 3 に示すようである。身長, 体 重, 足長 (右, 左), 足幅 (右, 左) はいずれも男子 の方が大であった。

重心動摇面積は開眼で男子 $16.2 \mathrm{~cm}^{2}$, 女子 $15.3 \mathrm{~cm}^{2}$, 閉眼で男子 $25.8 \mathrm{~cm}^{2}$, 女子 $21.2 \mathrm{~cm}^{2}$, 重心動摇距離は 開眼で男子 $52.8 \mathrm{~cm}$, 女子 $51.5 \mathrm{~cm}$, 閉眼で男子 83.7 $\mathrm{cm}$, 女子 $71.0 \mathrm{~cm}$ でありいずれあ男子より女子の方 が小さく, 閉眼時の重心動摇面積, 重心動摇距離にお
いては $\mathrm{P}<0.01$ で有意差が認められた。

男子の重心動摇面積 (開眼, 閉眼) の分布は図 1 に 示すようである。この值を対数変換して正規確率紙に プロットしたところ, ほぼ開眼, 閉眼とも一直線にな った。従って近似的に対数正規分布をしていると言え る。このことは女子についても同様に認められた。ま た, 重心動摇距離 (開眼, 閉眼) の分布においても男 女とも近似的に対数正規分布を示していた。

一般に対数正規型の分布は中央值をその代表值とし た方が正確とされており, その中央值を求めてみる と, 重心動摇面積開眼では男子 $14.7 \mathrm{~cm}^{2}$, 女子 13.7 $\mathrm{cm}^{2}$, 同閉眼では男子 $23.0 \mathrm{~cm}^{2}$, 女子 $19.0 \mathrm{~cm}^{2}$, 重心 動摇距離開眼男子 $50.9 \mathrm{~cm}$, 女子 $49.8 \mathrm{~cm}$, 同閉眼男 子 $78.3 \mathrm{~cm}$, 女子 $67.1 \mathrm{~cm}$ となり, 表 3 亿示す平均值 より，低くなる。 
Table 3. Means and standard deviations of values for physical characteristics and area and length of electrogravitiogram (EGG).

\begin{tabular}{llcccc}
\hline & & Boys & Girls & \multicolumn{1}{c}{ Total } \\
\hline & & $\bar{X}$ S.D. & $\bar{X}$ S.D. & $\bar{X}$ S.D. \\
\hline Height & & $93.2(3.4)$ & $92.7(3.2)$ & $92.9(3.3)$ & $\mathrm{cm}$ \\
Weight & & $13.8(1.5)$ & $13.4(1.5)$ & $13.6(1.5)$ & $\mathrm{kg}$ \\
Length of Foot & (right) & $15.0(0.9)$ & $14.8(0.8)$ & $14.9(0.9)$ & $\mathrm{cm}$ \\
& (left) & $14.9(0.9)$ & $14.8(0.8)$ & $14.8(0.8)$ & $\mathrm{cm}$ \\
Width of Foot & (right) & $6.2(0.4)$ & $6.1(0.4)$ & $6.1(0.4)$ & $\mathrm{cm}$ \\
& (left) & $6.2(0.4)$ & $6.1(0.4)$ & $6.1(0.4)$ & $\mathrm{cm}$ \\
Area of EGG & (eyes open) & $16.2(7.3)$ & $15.3(7.5)$ & $15.7(7.4)$ & $\mathrm{cm} / 20 \mathrm{~s}$ \\
& (eyes closed) & $25.8(12.6)$ & $21.2(11.4)$ & $23.2(12.1)$ & $\mathrm{cm} / 20 \mathrm{~s}$ \\
Length of EGG & (eyes open) & $52.8(15.4)$ & $51.5(14.3)$ & $52.1(14.8)$ & $\mathrm{cm} / 20 \mathrm{~s}$ \\
& (eyes closed) & $83.7(29.7)$ & $71.0(25.3)$ & $76.5(30.0)$ & $\mathrm{cm} / 20 \mathrm{~s}$ \\
\hline Number of Subjects & 278 & 367 & 645 & \\
\hline
\end{tabular}

** : statistically significant sex difference at the $1 \%$ level.

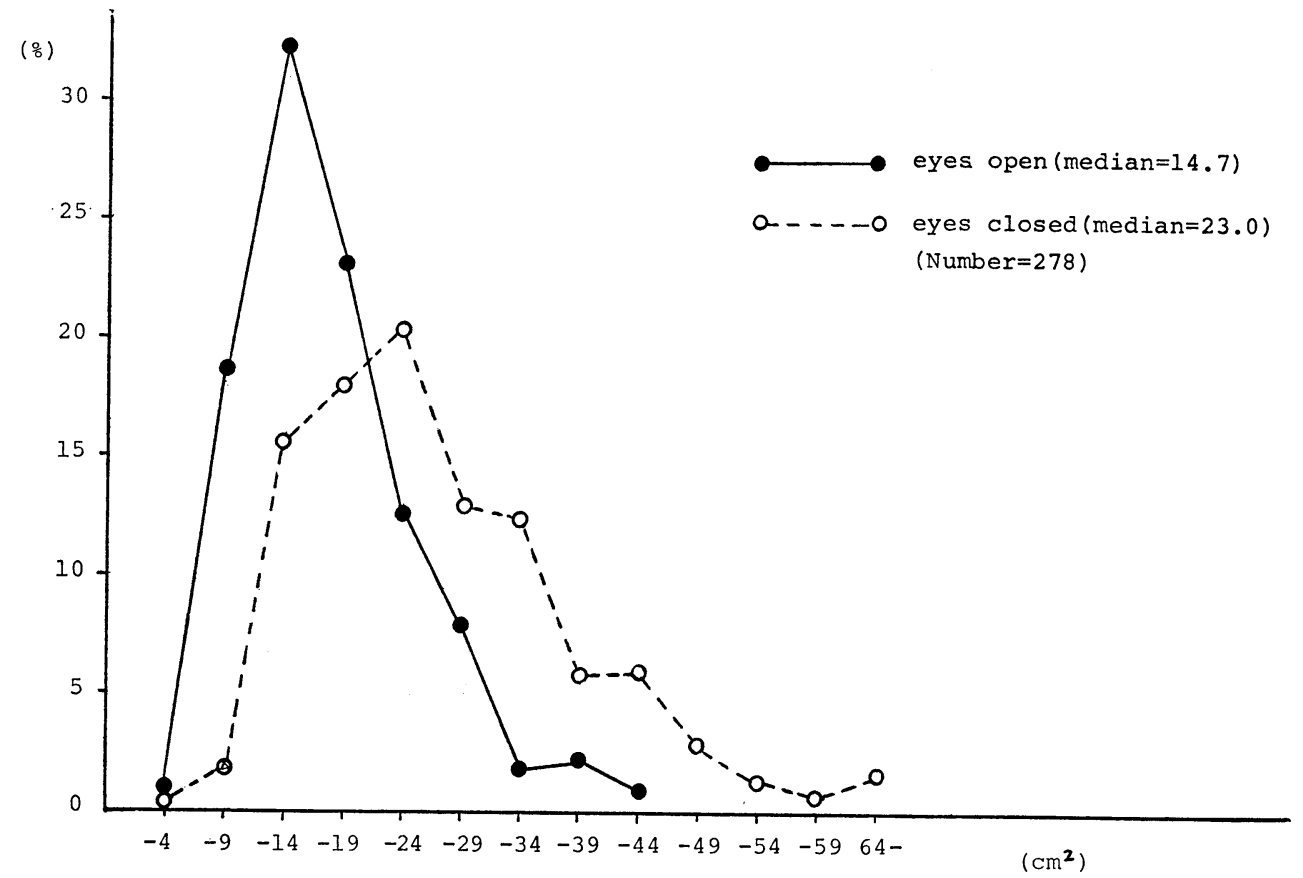

Fig. 1. Distribution of area of electrogravitiogram among boys. 
Table 4. Comparison of eyes closed/eyes open at area and length of electrogravitiogram (EGG).

\begin{tabular}{lccc}
\hline & Boys & Girls & Total \\
\hline & $\overline{\mathrm{X}}$ S.D. & $\overline{\mathrm{X}}$ S.D. & $\overline{\mathrm{X}}$ S.D. \\
\hline Area of EGG & $1.8(1.1)$ & $1.6(0.9)$ & $1.7(1.0)$ \\
Length of EGG & $1.7(0.7)$ & $1.4(0.5)$ & $1.5(0.6)$ \\
\hline Number of Subjects & 278 & 367 & 645 \\
\hline
\end{tabular}

Tabl 5. Correlation coefficient among area and length of electrogravitiogram (EGG).

\begin{tabular}{lcc}
\hline & Boys & Girls \\
\hline area (open) : length (open) & ${ }^{* *} 0.53$ & ${ }^{* *} 0.61$ \\
area (open) : area (closed) & ${ }^{* *} 0.27$ & ${ }^{* *} 0.34$ \\
area (open) : length (closed) & ${ }^{*} 0.13$ & ${ }^{* *} 0.24$ \\
area (closed) : length (open) & $* 0.16$ & $* * 0.22$ \\
area (closed : length (closed) & $* * 0.63$ & $* 0.66$ \\
length (open) : length (closed) & ${ }^{* *} 0.23$ & ${ }^{* *} 0.31$ \\
\hline Number of Subjects & 278 & 367 \\
\hline
\end{tabular}

**: statistically significant at $1 \%$ level.

*: statistically significant at $5 \%$ level.

開眼と閉眼の值では男女とも閉眼の方が大きかった ので表 4 亿示すように, 重心動摇面積, 重心動摇距離 の開眼時と閉眼時の比 (閉眼/開眼)をとってみた。 重心動摇面積では男子 1.8 , 女子 1.6 であり, 重心動 摇距離では男子 1.7 , 女子 1.4 であり, 女子の方がそ の比は小さかった。

重心動摇面積之重心動摇距離の相関係数は表 5 亿示 すようであり, 全般的に男子より女子の相関係数の方 が大きい。また, 男女とも開眼の面積と距離, 閉眼の 面積と距離との相関が強く, それに比べて開眼の面積 之閉眼の面積, 開眼の距離と閉眼の距離の相関は低か った。開眼の面積と閉眼の距離, 開眼の距離と閉眼の 面積の相関は最む低かった。しかし表 5 亿示すように すべてに扔いて危険率 $5 \%$ \%いし，1\%以下で有意の 相関関係が認められている。

重心動摇に影響を及ぼすと考えられる 3 才児の発㕕 状況, アンケート調査項目一歩きはじめた時期 (10, $11 ， 12 ， 13 ， 14$ 个月), 出生順位別 (第 1 子, 第 2 子, 第 3 子), 遊び場 (ある,なし), $50 \mathrm{~cm}$ の高さから飛 び降り(できる, できない)一, 身長別, 体重別, 足 長別, 足幅別について動摇面積, 動摇距離を比較して みたがはっきりとした傾向を見い出すととはできなか
った。

考察

今回使用した重心動摇計は臨床神経領城においても 簡便に用いることができるように開発されたすのであ り，その有用性や信頼性についてはすでに実証されて いる（平沢 $1974 ・ 1976$ ・ 1977; 岡部他 1975; 小沢他 1975 - 1976; 白井他 1976; 石川他 1976; 尾林他 197 $6)$ 。

一般に重心動摇面積は10才代後半まで加令と共に減 少し，10才代後半から20才代にかけて最も動摇性が少 なくなる。その後は加令と共に再び動摇性が増すこと が認められている（岡部 1975; 平沢他 1977)。本調 查においてあ36 38ケ月児より39ケ月児の重心動摇面 積, 距離が小さかったが, このととは上記のととを裏 づけたあのと言える。

重心動摇面積の男女の比較では開眼, 閉眼とも年少 者においては女子の動摇性の方が小さいととが報告さ れており（岡部 1975; 平沢 1977), また, 他の測定 機器を用いた調査においても低年令の女子の重心動摇 の優位性は認められている（横田他 1972; 川岸他 19 75)。この女子の優位性については本調査においても 
同様に認められている。乙の低年令層の重心動摇にお ける女子の優位性は如何なるものに起因するのかの究 明は今後の重要な課題である。今までに重心動摇計に よって求められた男女別の平均值（主に平沢 1977 ; 岡部 1975）に本調査の 3 才児の重心動摇面積, 距離 の值を加えると, ほぼ重心動摇検查が可能な 3 才児か らの全年令の平均值が求められたととになる。

岡部（1975）は疾患別（神経疾患々者）の特徵を明 らかにするために, 開眼時と閉眼時の重心動摇面積の 絶対值とそれらの比を出し, 小脳性疾患では開眼時で すでに正常者の約 3 倍を有し，閉眼による動摇性す正 常者の閉眼/開眼より大きいてとを報告している。今 回の 3 才児の閉眼による影響は面積で 1.7 倍, 距離で 1.5 倍あり, 岡部 (1975) の0〜9才の 9 例の值 (2.0) より小さかったが例数や年令（本調査では月令36〜38 ケ月）が違うことにより比較は難しい。

3 才児健康診査におけるいくつかの項目（運動能力 はじめ, 歩きはじめた時期, 遊び場, 出生順位, 居住 場所, 身長, 体重) と重心動摇面積, 同距離とをク口 スして比較してみたがはっきりとした傾向はあらわれ なかった。

重心動摇の記録は筋・骨格および神経系諸機能の能 力を表わすむのと言われている。3才児の運動能力を はじめとする他の要因との関連については今後更に例 数を増やすととあに, 測定を吟味して（いわゆるB， Cグループをなくす) 追求していきたい。

\section{要 約}

名古屋市内 $\mathrm{M}$ 保健所において通常行なわれている3 才児健診に重心動摇計による検査を加え，3才児の重 心動摇の測定を行なった。

結果は以下に示すようである。

1） 3 才児の約 5 割が重心動摇計による検査をする ことができ，男子より女子の方が成功率が高かった。

2）重心動摇面積は開眼男子 $16.2 \mathrm{~cm}^{2}$, 女子 15.3 $\mathrm{cm}^{2}$, 同閉眼男子 $25.8 \mathrm{~cm}^{2}$, 女子 $21.2 \mathrm{~cm}^{2}$ であり, 重心動摇距離では開眼男子 $52.8 \mathrm{~cm}$, 女子 $51.5 \mathrm{~cm}$, 同閉眼男子 $83.7 \mathrm{~cm}$, 女子 $71.0 \mathrm{~cm}$ である。重心動 摇面積ならびに重心動摇距離のいずれも男子より女子 の方が優れていた。

3）重心動摇面積ならびに重心動摇距離の分布は男 女とも近似的に対数正規分布を示している。

4）閉眼によって重心動摇面積ならびに重心動摇距 離は男女ともに増大し, 面積でおよそ開眼の 1.7 倍, 距離で 1.5 倍増大する。

\section{文献}

船川幡夫・平井信義・中山健太郎他, 1968：3才児健 康診査の方法に関する研究, 第 1 報, 研究のねらい およびアンケート項目について. 小児保健研究, 26 (3) : 113-128.

船川幡夫・平井信義・中山健太郎他, 1968：3才児健 康診査の方法に関する研究, 第 2 報, 妥当性の検討 と実施上の問題について. 小児保健研究, 26(4)： 161-172.

平沢彌一郎・青木賢一, 1977 : 日本人の直立能力につ いて. 第 2 回姿勢シンポジウム論文集, 41-46.

平沢彌一郎，1974：スタシオロジー(6)，巟童の直立 能力の発達之生活環境. 静岡大学教養部研究報告, 10号：47-70.

平沢彌一郎, 1976: スタシオロジー(8), 航空機騒音 が学童の直立能力に及ぼす影響について．静岡大学 教养部研究報告, 第12号 : 43-64.

堀田之, $1967 ： 3$ 才児期における身体発育について. 小児保健研究，24(6)：247-249.

堀田之, $1968 ： 3$ 才児期における身体発育について, 第 2 報. 小巟保健研究, 26(4): 178-179.

石川哲・小沢治夫・臼井永男, 1976 ：正常者ならびに 運動失調者における身体の平衡に関する視覚系の影 響. 最新医学, 31(2):254-263.

伊藤玲子・金野直子, $1970 ： 3$ 才児健診のアンケート ならびに精神発達調査について. 小児保健研究, 28 (2) : 86-92.

川岸与志男・奥田英二・杉江律, 1975 ：立位姿勢にお ける身体動摇度. 岐大教養部研究報告, 10号：177184.

尾林満子・小沢治夫・臼井永男・石川哲, 1976：内斜 視患者の身体平衡機能に関して. 臨床眼科, 30(11) : 1265-1269.

小沢治夫 - 曰井永男 - 大戸建, 1976 : 佐久地区児童生 徒の平衡機能. 眼科臨床医報, 70(6)：679-682.

岡部多加志, 1975 ：神経内科領域における二次元重心 動摇記録装置の臨床的応用. 慶応医学, 52(4)：265277.

小沢治夫・臼井永男・平沢彌一郎・尾林満子・石川哲, 1975 ：重心計による平衡機能と眼球運動. 眼科臨㕅 医報, 69(8)：1057-1059.

鈴木貞雄・川原ルリ, 1970：3才児健診における発達 検查による精神医学的研究. 小児保健研究, 29 (1) : 15-23.

臼井永男 - 小沢治夫 - 石川哲, 1976 : 眼球運動負荷に よる EGG について。眼科臨床医報, 70(3)：284287. 


\title{
Studies on the Standing Posture of 3 Year Old Children by Electrogravitiogram
}

\author{
Tsuneji Muramatsu' ${ }^{1)}$, Takeo Nakagawa ${ }^{2)}$, Fumio Kobayashi ${ }^{2)}$, \\ Seiichi KANEDA ${ }^{2)}$, Masako TANAHASHI ${ }^{2)}$, and katsumi YAMANAKA ${ }^{2)}$ \\ 1) Department of Health Education, Aichi University of Education \\ 2) Department of Public Health, Nagoya University School of Medicine
}

The movement of the point of the gravity (Electrogravitiogram, EGG) on both feet for 20 seconds of 1738 boys and girls was measured by a gravicorder (Anima Type G 1800) at the health examination for 3 year old children (at M-Health Center) in Nagoya City in November 1977 to in October 1978.

The results obtained in the study are as follows;

1) The percentage of achievement on the test is higher in girls than in boys.

2) The average area of EGG for boys are $16.2 \mathrm{~cm}^{2}$ (eyer open) and $25.8 \mathrm{~cm}^{2}$ (eyes closed), and that for girls are $15.3 \mathrm{~cm}^{2}$ (eyes open) and $21.2 \mathrm{~cm}^{2}$ (eyes closed). The average length of EGG for boys are $52.8 \mathrm{~cm}$ (eyes open) and $83.7 \mathrm{~cm}$ (eyes closed), and that for girls are $51.5 \mathrm{~cm}$ (eyes open) and $71.0 \mathrm{~cm}$ (eyes closed).

There was significant defference between boys and girls both in the area and the length of EGG.

3) Almost every area and length of EGG scattered along the logarithmic normal curve.

4) The area and length of EGG were increased by eyes closure in all children. The area of EGG at eyes closed status is 1.7 times as wide as that of eyes open status. The length of EGG at eyes closed status is 1.5 times as long as that eyes open status. 